\title{
Sistem Akuntansi Persediaan Pada CV. Ananda Putra Banyuasin
}

\author{
Muhamad Najib ${ }^{1}$, Totok Sudiyanto ${ }^{2}$,Santi Puspita ${ }^{3}$ \\ ${ }^{1}$ FKIP Universitas PGRI Palembang, mn760503@gmail.com \\ 2 Fakultas Ekonomi Universitas PGRI Palembang, totoktajir78@univpgri-palembang.ac.id \\ ${ }^{3}$ Fakultas Ekonomi Universitas PGRI Palembang, santipuspita@univpgri-palembang.ac.id
}

\begin{abstract}
CV. Ananda Putra Banyuasin is a manufacturing company located in Banyuasin Regency. This study aims to determine the implementation of the inventory accounting system at CV. Ananda Putra Banyuasin, which can be useful for the company to help improve the existing system. The data obtained is data from the company, namely in the form of company history data, organizational structure, tasks and functions as well as data related to the inventory accounting system, especially procedures for returning warehouse raw materials. The data analysis method in this research is quantitative analysis which analyzes the data, by collecting data related to the inventory accounting system obtained during the research, then comparing and analyzing the data obtained to conclude with existing theories. The results of this study show that in the procedure for returning inventory to the warehouse at CV. Ananda Putra Banyuasin, there is no written evidence in the form of documents or letters to return raw material supplies to the warehouse, so there is often a difference between the warehouse inventory records and the inventory records owned by the warehouse. Supply Card Section. So a good system and procedure for companies uses written evidence, so there is no discrepancy in the raw material inventory records.
\end{abstract}

Keywords: Inventory Accounting System

\begin{abstract}
ABSTRAK
CV. Ananda Putra Banyuasin merupakan perusahaan manufaktur yang berlokasi di Kabupaten Banyuasin. Penelitian ini bertujuan untuk mengetahui pelaksanaan sistem akuntansi persediaan pada CV. Ananda Putra Banyuasin, yang dapat bermanfaat bagi perusahaan untuk membantu memperbaiki sistem yang ada. Data yang di peroleh merupakan data dari perusahaan yaitu berupa data sejarah perusahaan, struktur organisasi, tugas dan fungsi serta data yang berhubungan dengan sistem akuntansi persediaan khususnya prosedur pengembalian persediaan bahan baku gudang. Metode analisis data dalam penelitian ini adalah analisis kuantitatif yang menganalisa data, dengan cara mengumpulkan data yang berkaitan dengan sistem akuntansi persediaan yang diperoleh saat penelitian, kemudian membandingkan serta menganalisa data yang diperoleh tersebut untuk disimpulkan dengan teori yang ada. Adapun hasil penelitian ini bahwa dalam prosedur pengembalian persediaan ke gudang pada CV. Ananda Putra Banyuasin, tidak ada bukti tertulis berupa dokumen atau surat pengembalian persediaan bahan baku ke gudang, sehingga sering terjadi selisih antara catatan persediaan Bagian Gudang dengan catatan persediaan yang dimiliki oleh Bagian Kartu Persediaan. Maka sistem dan prosedur yang baik untuk perusahaan menggunakan bukti tertulis, sehingga tidak terjadi selisih catatan persediaan bahan baku.
\end{abstract}

Kata Kunci : Sistem Akuntansi Persediaan

\section{A. PENDAHULUAN}

Setiap perusahaan dalam menjalankan aktivitas usahanya selalu berusaha agar apa yang telah ditetapkan dapat dicapai semaksimal mungkin terutama dalam mengoptimalkan laba. Setiap usaha yang telah berjalan harus dimonitor aktivitas usahanya dan pihak manajemen harus berusaha untuk mengendalikan dan 
mengarahkan semua sumber daya yang dimiliki agar berjalan efektif dan efisien. Perusahaan yang bergerak dalam bidang industri, dagang maupun jasa harus mempunyai pengendalian yang disusun sesuai dengan aktivitas dan kebutuhan organisasi perusahaan.

Perusahaan manufaktur merupakan perusahaan yang melakukan proses perubahan bentuk dari bahan baku kemudian melalui suatu proses menjadi produk jadi, kemudian dijual kepada konsumen atau anggota distribusi produksi lainnya. Salah satu unsur yang paling efektif dalam perusahaan manufaktur adalah barang jadi atau sering disebut dengan persediaan.

Sistem akuntansi persediaan bertujuan mencatat mutasi tiap jenis persediaan yang disimpan digudang. Menghadapi masalah yang mungkin timbul, maka diperlukan adanya suatu sistem akuntansi persediaan yang baik dan efisien seperti pelaksanaan perhitungan persediaan menggunakan metode perhitungan fisik atau perpetual, proses pencatatan persediaan harus benar karena akan berpengaruh kepada jumlah persediaan barang yang berada di gudang. Persediaan merupakan investasi yang penting dalam memerlukan perhatian yang besar, karena tanpa adanya persediaan yang cukup, maka kelangsungan hidup perusahaan tidak dapat berjalan dengan baik dan pada akhirnya akan mengalami kerugian yang besar. (Oktariansyah, 2019)

CV. Ananda Putra Banyuasin adalah perusahaan manufaktur yang berlokasi di Kabupaten Banyuasin. CV. Ananda Putra Banyuasin memproduksi Vinir dengan menggunakan bahan baku kayu karet dan Sengon, yang bahan bakunya didapat dari perkebunan rakyat di Kabupaten OI, OKI, dan Kota Prabumulih. Vinir merupakan lembaran tipis kayu yang dihasilkan melalui beberapa proses mesin. Vinir yang diproduksi pun bervariasi tergantung dari fungsi dan pemakaiannya. Vinir digunakan untuk lapisan akhir sebuah plywood (multipleks) atau papan buatan lainnya biasanya cukup tipis namun berkualitas baik terutama dari sisi estetika atau keindahan. Vinir yang diproduksi dikirim ke pusat atau CV. Ananda Putra Banyuasin dan sebagian lagi disimpan di gudang.

Proses produksi vinir menggunakan persediaan bahan baku seperti kayu sengon. Apabila bahan baku berupa sengon tidak habis dalam satu kali produksi maka persediaan tersebut akan dikembalikan ke gudang. Dalam prosedur pengembalian persediaan ke gudang pada CV. Ananda Putra Banyuasin, tidak ada bukti tertulis berupa dokumen atau surat pengembalian persediaan bahan baku ke gudang, akibatnya petugas Bagian Gudang sering lupa melaporkan ke Bagian Kartu Persediaan (Akuntansi) bahwa terdapat persediaan yang dikembalikan ke gudang. Sehingga sering terjadi selisih antara catatan persediaan Bagian Gudang dengan catatan persediaan yang dimiliki oleh Bagian Persediaan

\section{B. KAJIAN TEORI}

\section{1) Sistem}

\section{a) Pengertian Sistem}

Untuk megetahui kebutuhan informasi baik dari dalam perusahaan maupun bagi pihak luar maka perlu disusun suatu sistem akuntansi. Mulyadi (2010:2) menyatakan bahwa "sistem adalah sekelompok unsur yang erat berhubungan satu dengan yang lainnya, yang berfungsi bersama-sama untuk mencapai tujuan tertentu." 
Widjajanto (2001:2) "sistem adalah sesuatu yang memiliki bagian-bagian yang saling berinteraksi untuk mencapai tujuan tertentu melalui tiga tahapan yaitu input, proses dan output."

Dari beberapa definisi diatas maka dapat disimpulkan bahwa sistem merupakan serangkaian prosedur yang saling berhubungan atau berkaitan satu sama lain untuk mencapai tujuan yang telah ditetapkan.

\section{b) Komponen sistem}

Menurut Winarno (2006:1.5) masing-masing komponen sistem memiliki fungsi sebagai berikut :

$>\quad$ Input berfungsi untuk menerima masukan dari luar sistem. Pesawat televisi menerima input siaran televise dari antena, atau bisa juga menerima input dari pemutar DVD dan kamera video melalui colokan input.

$>$ Proses berfungsi untuk mengubah input menjadi output. Pesawat televisi memiliki komponen berupa rangkaian elektronik di dalamnya, yang berfungsi mengubah sinyal menjadi gambar dan suara.

$>$ Output berfungsi untuk mengirimkan hasil olahan kepada pihak di luar sistem. Pesawat televisi memiliki layar yang berfungsi untuk menyampaikan keluaran (berbentuk gambar) dan memiliki speaker yang berfungsi untuk mengeluarkan suara.

$>$ Kontrol berfungsi untuk mengendalikan komponen lain agar berfungsi seperti yang diharapkan. Pesawat televisi memiliki stabilisator di dalamnya yang berfungsi menjaga kualitas gambar dan suara.

$>$ Batas sistem berfungsi untuk memisahkan sistem dengan lingkungannya atau dengan sistem lainnya. Pesawat televisi memiliki kotak yang memisahkannya dari perangkat lain.

$>$ Sistem juga memiliki tujuan yang hendak dicapai. Tujuan dari pesawat televisi adalah sebagai alat hiburan, meskipun bisa juga digunakan untuk pelajaran atau penjaga keamanan bangunan dan rumah. Itulah sebabnya pesawat televise dirancang dengan menarik, agar dapat diletakkan diruang keluarga atau di ruang tamu kantor, sehingga serasi dengan perabotan yang lain.

\section{c) Jenis-jenis sistem}

Menurut Winarno (2006:1.5) sistem dapat digolongkan ke dalam beberapa kelompok, tergantung karakteristiknya. Beberapa golongan sistem di antaranya adalah :

$>$ Sistem terbuka vs tertutup. Sistem terbuka adalah sistem yang berhubungan dengan lingkungannya. Sistem terbuka menerima masukan dari luar dan menghasilkan keluaran juga untuk pihak luar. Kebanyakan sistem bersifat terbuka. Sedangkan sistem tertutup adalah sistem yang berhubungan dengan lingkungannya.

$>$ Sistem manual vs otomatis. Sistem manual adalah sistem yang bekerja berdasarkan campur tangan orang. Tanpa dijalankan secara manual, sistem tidak akan berjalan. Sistem otomatis adalah sistem yang dapat bekerja sendiri secara otomatis, sehingga tidak memerlukan campur tangan manusia.

> Sistem alamiah vs buatan manusia. Sistem alamiah adalah sistem yang sudah disediakan oleh alam, sehingga manusia tidak dapat berbuat banyak untuk mempengaruhi sistem tersebut. Contohnya adalah sistem hujan, 
sistem tata surya, dan ekosistem. Sistem buatan manusia adalah sistem yang diciptakan oleh manusia.

$>$ Sistem statis vs dinamis. Sistem statis adalah sistem yang relatif tetap atau tidak berubah, sedangkan sistem dinamis adalah sistem yang selalu berubah menyesuaikan dengan lingkungannya.

Akuntansi dapat dilihat sistem yang terbuka (karena menerima input dari luar dan memberi informasi kepada pihak intern dan ekstern), dapat berupa sistem manual (bila dikerjakan dengan manual) maupun sistem otomatis (misalnya ATM), sistem buatan manusia, dan dilihat dari kegiatan intinya, yaitu pencatatan, akuntansi merupakan sistem yang statis, karena pada dasarnya hanya mencatat transaksi ke dalam jurnal, memindahkan ke buku besar, dan diakhiri dengan penyajian laporan keuangan.

\section{2) Sistem Akuntansi}

\section{a) Pengertian Sistem Akuntansi}

Menurut Mulyadi (2010:3) sistem akuntansi adalah organisasi formulir, catatan, dan laporan yang dikoordinasi sedemikian rupa untuk menyediakan informasi keuangan yang dibutuhkan oleh manajemen guna memudahkan pengelolaan perusahaan.

Dari definisi tersebut, unsur suatu sistem akuntansi pokok adalah formulir, catatan, yang terdiri dari jurnal, buku besar dan buku pembantu, serta laporan. Berikut ini diuraikan lebih lanjut pengertian masing-masing unsur sistem akuntansi tersebut.

$\checkmark$ Formulir

Formulir merupakan dokumen yang digunakan untuk merekam terjadinya transaksi. Formulir sering disebut dengan istilah dokumen, karena dengan formulir ini peristiwa yang terjadi dalam organisasi direkam (didokumentasikan) diatas secarik kertas. Formulir sering disebut dengan istilah media, karena formulir merupakan media untuk mencatat peristiwa yang terjadi dalam organsisasi ke dalam catatan. Dengan formulir ini, data yang bersangkutan dengan transaksi direkam pertama kalinya sebagai dasar pencatatan dalam catatan.

Dalam sistem akuntansi secara manual, media yang digunakan untuk merekam pertama kali data trnasaksi keuangan adalah formulir yang dibuat dari kertas. Dalam sistem akuntansi dengan komputer digunakan dalam berbagai macam media untuk memasukkan data kedalam sistem pengolahan data seperti papan ketik, program Microsoft Excel.

$\checkmark$ Jurnal

Jurnal merupakan catatan akuntansi pertama yang digunakan untuk mencatat, mengklasifikasikan, dan meringkas data keuangan dan data lainnya. Dalam jurnal ini, data keuangan untuk pertama kalinya diklasifikasikan menurut penggolongan yang sesuai dengan informasi yang akan disajikan dalam laporan keuangan. Dalam jurnal ini pula terdapat kegiatan peringkasan data yang hasilnya kemudian di-posting ke rekening yang bersangkutan dalam buku besar.

$\checkmark$ Buku Besar 
Buku besar terdiri dari rekening-rekening yang digunakan untuk meringkas data keuangan yang telah dicatat sebelumnya dalam jurnal. Rekening dalam buku besar ini disediakan sesuai dengan unsur-unsur informasi yang akan disajikan dalam laporan keuangan. Rekening buku besar ini di satu pihak dapat dipandang sebagai wadah untuk menggolongkan data keuangan, di pihak lain dapat dipandang pula sebagai sumber informasi keuangan untuk penyajian laporan keuangan.

$\checkmark$ Buku Pembantu

Jika data keuangan dalam buku besar diperlukan rinciannya lebih lanjut, dapat dibentuk buku pembantu. Buku rekening-rekening pembantu yang merinci data keuangan yang tercantum dalam rekening tertentu dalam buku besar. Buku besar dan buku pembantu merupakan catatan akhir akuntansi, yang berarti tidak ada lagi catatan akuntansi lain sesudah data akuntansi diringkas dan digolongkan dalam rekening buku besar dan buku pembantu.

$\checkmark$ Laporan

Hasil akhir akuntansi adalah laporan keuangan yang dapat berupa neraca, laporan rugi laba, laporan perubahan laba yang ditahan, laporan harga pokok produksi, laporan biaya pemasaran, laporan harga pokok penjualan, daftar umur piutang, daftar utang yang akan dibayar, daftar saldo persediaan yang lambat penjualannya. Laporan berisi informasi yang merupakan keluaran sistem akuntansi. Laporan dapat berbentuk hasil cetak komputer dan tayangan pada layar monitor komputer.

\section{b) Jenis-jenis Sistem Akuntansi dalam Perusahaan Manufaktur}

Menurut Mulyadi (2010:15) kegiatan pokok perusahaan manufaktur terdiri dari desain pengembangan produk, pengolahan bahan baku menjadi produk jadi, dan penjualan produk jadi kepada pembeli. Untuk menangani kegiatan pokok perusahaan, umumnya dirancang sistem akuntansi yang terdiri dari:

$>$ Sistem akuntansi pokok

Sistem akuntansi pokok merupakan organisasi formulir, catatan, dan laporan. Sistem akuntansi dalam perusahaan manufaktur terdiri atas formulir atau dokumen, jurnal, buku besar, buku pembantu, dan laporan. Unsur-unsur sistem akuntansi ini dirancang oleh manajemen untuk menyajikan informasi keuangan bagi kepentingan pengelolaan perusahaan dan pertanggungjawaban keuangan kepada pihak luar perusahaan seperti investor, kreditur, dan Kantor Pelayanan Pajak.

$>$ Sistem akuntansi piutang

Sistem akuntansi piutang dirancang untuk mencatat transaksi terjadinya piutang dan berkurangnya piutang. Terjadinya piutang berasal dari transaksi penjualan kredit dan berkurangnya piutang berasal dari transaksi retur penjualan dan penerimaan kas dari piutang. Transaksi berkurangnya piutang yang timbul dari transaksi penerimaan kas dari piutang dikelompokkan dalam sistem akuntansi kas. Kegiatan penjualan kredit dimulai dengan diterimanya order dari pelanggan, kemudian dilanjutkan dengan permintaan persetujuan pemberian kredit, pengiriman barang, penagihan, pencatatan piutang dan berakhir dengan distribusi penjualan.

$>$ Sistem akuntansi utang

Sistem akuntansi utang dirancang untuk mencatat transaksi terjadinya utang dan berkurangnya utang. Terjadinya utang berasal dari transaksi pembelian kredit dan berkurangnya utang berasal dari transaksi retur 
pembelian dan pelunasan utang. Kegiatan pembelian kredit dimulai dengan diajukannya permintaan pembelian barang ke fungsi pembelian, kemudian dilanjutkan dengan permintaan penawaran harga dan pemilihan pemasok, pengiriman order pembelian kepada pemasok terpilih, penerimaan barang yang dibeli, pencatatan utang yang timbul dari transaksi pembelian dan berakhir dengan distribusi pembelian.

$>$ Sistem akuntansi penggajian dan pengupahan

Sistem akuntansi penggajian dan pengupahan dirancang untuk menangani transaksi perhitungan gaji dan upah karyawan dan pembayarannya. Sistem ini terdiri dari jaringan prosedur pencatatan waktu hadir dan waktu kerja, prosedur pembuatan daftar gaji dan upah, prosedur pembayaran gaji dan upah, prosedur distribusi biaya gaji dan upah.

$>$ Sistem akuntansi biaya

Sistem akuntansi biaya dirancang untuk menangani pengendalian produksi dan pengendalian biaya. Sistem ini terdiri dari jaringan prosedur oder produksi, prosedur pengumpulan biaya produksi dan nonproduksi.

$>$ Sistem akuntansi kas

Sistem akuntansi ini dirancang untuk menangani transaksi penerimaan dan pengeluaran kas. Sistem ini terdiri dari jaringan prosedur penerimaan kas, prosedur pengeluaran kas, dan prosedur dana kecil.

$>$ Sistem akuntansi persediaan

Sistem akuntansi persediaan dirancang untuk menangani transaksi yang bersangkutan dengan mutasi persediaan yang disimpan digudang.

$>$ Sistem akuntansi aset tetap

Sistem akuntansi aset tetap dirancang untuk menangani transaksi yang bersangkutan dengan mutasi aset tetap.

\section{c) Tujuan Sistem Akuntansi}

Tujuan umum pengembangan sistem akuntansi menurut Mulyadi (2010:19) adalah sebagai berikut:

$>$ Untuk menyediakan informasi bagi pengelolaan kegiatan usaha baru

Kebutuhan pengembangan sistem akuntansi terjadi jika perusahaan baru didirikan atau suatu perusahaan menciptakan usaha baru yang berbeda dengan usaha yang telah dijalankan selama ini. Perusahaan manufaktur baru biasanya memerlukan pengembangan sistem akuntansi lengkap, sejak dari sistem akuntansi lengkap, sejak dari sistem akuntansi piutang, sistem akuntansi utang, sistem akuntansi penggajian dan pengupahan, sistem akuntansi biaya, sistem akuntansi kas, sistem akuntansi persediaan, sistem akuntansi aktiva tetap, dan sistem akuntansi pokok. Sedangkan perusahaan yang membuka usaha baru yang selama ini belum dijalankan biasanya memerlukan pengembangan sistem akuntansi yang tidak selengkap yang diperlukan oleh perusahaan baru.

> Untuk memperbaiki informasi yang dihasilkan oleh sistem yang sudah ada Adakalanya sistem akuntansi yang berlaku tidak dapat memenuhi kebutuhan manajemen, baik dalam hal mutu, ketepatan penyajian maupun struktur informasi yang terdapat dalam laporan. Hal ini kemungkinan disebabkan oleh perkembangan usaha perusahaan, sehingga menuntut sistem akuntansi untuk dapat menghasilkan laporan dengan mutu informasi 
yang lebih baik dan tepat penyajiannya, dengan struktur informasi yang sesuai dengan tuntutan kebutuhan manajemen.

$>$ Untuk memperbaiki pengendalian akuntansi dan pengecekan intern

Akuntansi merupakan alat pertanggungjawaban kekayaan suatu organisasi. Pengembangan sistem akuntansi seringkali ditujukan untuk memperbaiki perlindungan terhadap kekayaan organisasi sehingga pertanggungjawaban terhadap penggunaan kekayaan organisasi dapat dilaksanakan dengan baik. Pengembangan sistem akuntansi dapat pula ditujukan untuk memperbaiki pengecekan intern agar informasi yang dihasilkan oleh sistem tersebut dapat dipercaya.

$>$ Untuk mengurangi biaya klerikal dalam penyelenggaraan catatan akuntansi Pengembangan sistem akuntansi seringkali ditujukan untuk menghemat biaya. Informasi merupakan barang ekonomi. Untuk memperolehnya diperlukan pengorbanan sumber ekonomi yang lain. Oleh karena itu dalam menghasilkan informasi keuangan diperhitungkan lebih besar dibanding dengan manfaat yang diperoleh, sistem yang sudah ada perlu dirancang kembali untuk mengurangi pengorbanan sumber daya bagi penyediaan informasi tersebut.

Berdasarkan tujuan pengembangan sistem akuntansi tersebut di atas, penugasan pengembangan sistem akuntansi dapat berbentuk sebagai berikut:

1. Pengembangan suatu sistem akuntansi baru yang lengkap.

2. Perluasan sistem akuntansi yang sekarang dipakai untuk mencakup kegiatan bisnis yang baru.

3. Perbaikan terhadap sistem dan prosedur yang sekarang digunakan.

\section{3) Persediaan}

Menurut Rudianto (2009:24) persediaan adalah sejumlah barang jadi, bahan baku, barang dalam proses yang dimiliki perusahaan dengan tujuan untuk dijual atau diproses lebih lanjut.

Menurut Soemarso (2004:387) metode penetapan harga pokok persediaan ada beberapa yaitu sebagai berikut :

$>$ Metode FIFO (First In First-Out) adalah metode penetapan harga pokok persediaan yang didasarkan atas anggapan bahwa barang-barang terdahulu dibeli akan merupakan barang yang dijual pertama kali. Dalam metode ini persediaan akhir dinilai dengan harga pokok pembelian yang paling akhir.

$>\quad$ Metode LIFO (Last In First-Out) adalah metode penetapan harga pokok persediaan yang didasarkan atas anggapan bahwa barang-barang yang paling akhir dibeli akan merupakan barang yang dijual pertama kali. Dalam metode ini, persediaan akhir akan dinilai dengan harga pembelian yang terdahulu.

$>\quad$ Metode Rata-rata (average) adalah metode penetapan harga pokok persediaan di mana dianggap bahwa harga pokok rata-rata dari barang yang tersedia dijual akan digunakan untuk menilai harga pokok yang dijual dan yang terdapat dalam persediaan.

Menurut Rudianto (2009:106) terdapat dua metode pencatatan persediaan yaitu sebagai berikut: 
$\checkmark$ Metode Periodik adalah metode yang digunakan untuk mencatat hal-hal yang berkaitan dengan persediaan barang dagangan di dalam perusahaan dagang, dimana persediaan dicatat dan dihitung hanya pada awal dan akhir periode akuntansi saja untuk menentukan harga pokok penjualannya. Metode ini paling banyak dipakai oleh perusahaan yang frekuensi transaksinya tinggi

$\checkmark$ Metode Perpetual adalah metode yang digunakan untuk mencatat hal-hal yang berkaitan dengan persediaan barang dagangan di dalam perusahaan dagang, dimana persediaan dicatat dan dihitung secara detail, baik pada waktu dibeli maupun dijual. Metode ini lebih cocok digunakan di dalam perusahaan yang memiliki frekuensi transaksi tidak terlalu tinggi tetapi nilai per transaksinya besar.

\section{4) Sistem Akuntansi Persediaan}

Krismiaji (2010:399) sistem persediaan merupakan sebuah sistem yang memelihara catatan persediaan dan memberitahu manajer apabila jenis barang tertentu memerlukan penambahan. Dalam perusahaan manufaktur, sistem persediaan mengendalikan tingkat (jumlah) bahan baku dan jumlah produk jadi.

Menurut Mulyadi (2010:553) sistem akuntansi persediaan bertujuan untuk mencatat mutasi tiap jenis persediaan yang disimpan di gudang. Dalam perusahaan manufaktur, persediaan terdiri dari persediaan produk jadi, persediaan produk dalam proses, persediaan bahan baku, persediaan bahan penolong, persediaan bahan habis pakai pabrik, dan persediaan suku cadang.

Menurut Mulyadi (2010:560-575) sistem dan prosedur yang bersangkutan dengan sistem akuntansi persediaan adalah:

a) Prosedur pencatatan produk jadi

$>$ Deskripsi prosedur

Dalam prosedur ini dicatat harga pokok produk jadi yang didebitkan ke dalam rekening persediaan produk jadi dan dikreditkan ke dalam rekening barang dalam proses.

$>$ Dokumen

Dokumen yang digunakan dalam prosedur pencatatan produk jadi adalah laporan produk selesai dan bukti memorial. Laporan produk selesai digunakan oleh bagian gudang untuk mencatat tambahan kuantitas produk jadi dalam kartu gudang. Bukti memorial digunakan untuk mencatat tambahan kuantitas dan harga pokok persediaan produk jadi dalam kartu persediaan dan digunakan sebagai dokumen sumber dalam mencatat transaksi selesainya produk jadi dalam jurnal umum.

> Bagan alir dokumen Prosedur pencatatan produk jadi

Pencatatan harga pokok produk jadi dilakukan dengan mendebit rekening persediaan produk jadi dan mengkredit rekening Barang dalam Proses. Disamping itu, kartu gudang yang diselenggarakan di fungsi gudang diisi dengan tambahan kuantitas persediaan produk jadi yang disimpan digudang. Pencatatan harga pokok produk jadi dilakukan oleh Bagian Kartu Persediaan berdasarkan laporan produk selesai yang diterima oleh Bagian Kartu Persediaan dari Bagian Produksi. Berdasarkan laporan produk selesai tersebut, Bagian Kartu Persediaan dari Bagian menghitung harga pokok produk selesai berdasarkan data biaya produksi yang telah dikumpulkan dalam kartu harga pokok produk pesanan yang bersangkutan. Total harga 
merupakan dokumen sumber bagi Bagian Kartu Persediaan untuk mencatat harga pokok produk selesai dalam kartu persediaan.

b) Prosedur pencatatan harga pokok produk yang dijual

$>$ Deskripsi prosedur

Prosedur ini merupakan salah satu prosedur dalam sistem penjualan disamping prosedur lainnya seperti: prosedur order penjualan, prosedur persetujuan kredit, prosedur pengiriman barang, prosedur penagihan, prosedur pencatatan piutang.

Dokumen

Dokumen sumber yang digunakan untuk mencatat transaksi penjualan produk jadi adalah surat order pengiriman diterima oleh bagian gudang dari bagian order penjualan. Setelah bagian gudang mengisi surat order pengiriman barang tersebut dengan kuantitas produk jadi yang diserahkan kepada bagian pengiriman, atas dasar surat order pengiriman tersebut bagian gudang mencatat kuantitas yang diserahkan ke bagian pengiriman dalam kartu gudang. Harga pokok produk jadi yang dijual dicatat oleh bagian kartu persediaan.

$>$ Catatan Akuntansi

Catatan akuntansi yang digunakan dalam prosedur pencatatan harga pokok produk jadi yang dijual adalah: kartu gudang, kartu persediaan, jurnal umum. Dalam prosedur pencatatan harga pokok produk jadi yang dijual, kartu gudang berfungsi untuk mencatat mutasi kuatitas persediaan produk jadi karena transaksi penjualan, sedangkan kartu persediaan berfungsi untuk mencatat mutasi kuantitas dan harga pokok persediaan produk jadi yang dijual. Jurnal umum digunakan untuk mencatat jurnal harga pokok produk jadi yang dijual untuk diposting ke dalam rekening kontrol persediaan produk jadi.

$>$ Bagan alir dokumen prosedur pencatatan harga pokok produk jadi yang dijual.

Bagian Kartu Persediaan secara periodic membuat rekapitulasi harga pokok produk yang dijual selama periode tertentu berdasarkan data yang direkam dalam kartu persediaan. Total harga pokok produk yang dijual selama periode tertentu yang dicantumkan dalam rekapitulasi harga pokok penjualan dan dipakai oleh Bagian Kartu Persediaan untuk embuat bukti memorial.

c) Prosedur pencatatan harga pokok produk jadi yang diterima kembali dari pembeli

$>$ Deskripsi Prosedur

Jika produk jadi yang telah dijual dikembalikan oleh pembeli, maka transaksi retur penjualan ini akan mempengaruhi persediaan produk jadi, yaitu menambah kuantitas produk jadi dalam kartu gudang yang diselenggarakan oleh Bagian Gudang dan menambah kuantitas dan harga pokok produk jadi yang dicatat oleh Bagian Kartu Persediaan dalam kartu persediaan produk jadi. Prosedur ini merupakan salah satu prosedur yang membentuk sistem retur penjualan.

$>$ Dokumen

Dokumen yang digunakan dalam prosedur pencatatan harga pokok produk jadi yang dikembalikan oleh pembeli adalah: laporan penerimaan barang dan 
memo kredit. Laporan penerimaan barang digunakan oleh Bagian Gudang untuk mencatat kuantitas produk jadi yang diterima dari pembeli kedalam kartu gudang. Memo kredit yang diterima dari bagian order penjualan digunakan oleh Bagian Kartu Persediaan untuk mencatat kuatitas dan harga pokok produk jadi yang dikembalikan oleh pembeli ke dalam kartu persediaan.

> Bagan alir dokumen Prosedur Pencatatan Harga Pokok Produk Jadi yang diterima kembali dari Pembeli

Pencatatan Harga Pokok Produk Jadi yang diterima kembali dari Pembeli dilakukan dengan mendebit rekening persediaan produk jadi dan mengkredit rekening Harga Pokok Penjualan. Di samping itu, kartu gudang yang diselenggarakan di fungsi gudang diisi dengan tambahan kuantitas persediaan produk jadi yang diterima kembali dari pembeli.

Harga pokok produk jadi yang diterima kembali oleh Bagian Gudang dari pembeli dicatat oleh Bagian Kartu Persediaan dan Bagian Jurnal.

Pencatatan harga pokok produk jadi yang diterima dari pembeli dilakukan oleh Bagian Kartu Persediaan berdasarkan memo kredit yang diterima oleh Bagian Kartu Persediaan yang dari Bagian penerimaan melalui Bagian Piutang. Berdasarkan memo kredit tersebut, Bagian Kartu Persediaan mengisi harga pokok produk jadi yang diterima kembali berdasarkan data harga pokok per unit tercantum dalam kartu persediaan yang bersangkutan. Total harga pokok persediaan dicantumkan di dalam bukti memorial dan dipakai oleh Bagian Kartu Persediaan sebagai dokumen sumber dalam pencatatan ke kartu persediaan.

d) Prosedur pencatatan tambahan dan penyesuaian kembali harga pokok persediaan produk dalam proses

$>$ Deskripsi Prosedur

Pencatatan persediaan produk dalam proses umumnya dilakukan oleh perusahaan pada akhir periode, pada saat dibuat laporan keuangan bulanan dan laporan keuangan tahunan.

$>$ Dokumen

Dokumen yang digunakan dalam prosedur pencatatan persediaan produk dalam proses adalah bukti memorial. Bukti memorial ini dilampiri dengan laporan produk dalam proses digunakan untuk mencatat jurnal tambahan harga pokok persediaan produk dalam prosesdalam jurnal umum. Bukti memorial juga digunakan sebagai dokumen sumber dalam mencatat readjustment persediaan harga pokok produk dalam proses. Dalam prosedur pencatatan persediaan produk dalam proses, Bagian Gudang tidak melakukan pencatatan persediaan produk dalam proses karena secara fisik persediaan tersebut tidak ditransfer dari Bagian Produksi ke Bagian Gudang. Begitu pula Bagian Kartu Persediaan tidak melakukan pencatatan persediaan produk dalam proses tersebut dalam kartu persediaan.

> Bagan alir dokumen prosedur pencatatan harga pokok produk dalam proses. Bagian Kartu Persediaan melakukan penghitungan harga pokok persedian produk dalam proses pada akhir periode akuntansi berdasarkan data yang dikumpulkan dalam kartu harga pokok produk. Laporan produk dalam proses yang diterima oleh Bagian Kartu Persediaan dari Bagian Produksi berisi informasi kuantitas produk dalam proses dan taksir-an tingkat penyelesaian 
produk dalam proses yang ada di fungsi produksi pada akhir periode akuntansi.

e) Prosedur pencatatan harga pokok persediaan yang dibeli

$>$ Deskripsi Prosedur

Prosedur ini merupakan salah satu prosedur yang membentuk sistem pembelian. Dalam prosedur ini dicatat harga pokok persediaan yang dibeli.

$>$ Dokumen

Dokumen yang digunakan dalam prosedur pencatatan harga pokok persediaan yang dibeli adalah laporan penerimaan barang dan bukti kas keluar. Laporan penerimaan barang digunakan oleh Bagian Gudang sebagai dasar pencatatan tambahan kuantitas barang dari pembelian ke dalam kartu gudang. Bukti kas keluar yang dilampiri dengan laporan penerimaan barang, surat order pembelian, dan faktur dari pemasok dipakai sebagai dokumen sumber dalam pencatatan harga pokok persediaan yang dibeli dalam register bukti kas keluar. Bukti kas keluar juga dipakai sebagai dasar pencatatan tambahan kuantitsa dan harga pokok persediaan ke dalam kartu persediaan.

$>$ Bagan alir dokumen prosedur pencatatan harga pokok persediaan yang dibeli.

Bagian utang membuat bukti kas keluar sebagai dokumen sumber pencatatan harga pokok persediaan yang dibeli berdasarkan dokumen pendukung: surat order pembelian yang diterima dari bagian penerimaan, dan faktur dari pemasok yang diterima dari pemasok melalui Bagian Pembelian. Oleh Bagian Utang, bukti kas keluar dicatat dalam bentuk jurnal di dalam register bukti kas keluar. Berdasarkan bukti kas keluar, Bagian Kartu Persediaan mencatat rincian persediaan yang dibeli di dalam kartu persediaan yang bersangkutan. Bagian Gudang mencatat tambahan kuantitas persediaan yang dibeli di dalam kartu gudang berdasarkan laporan penerimaan barang yang diterima oleh Bagian Gudang dari bagian Pengiriman.

f) Prosedur pencatatan harga pokok persediaan yang dikembalikan kepada pemasok

\section{$>$ Deskripsi Prosedur}

Jika persediaan yang telah dibeli dikembalikan kepada pemasok, maka transaksi retur pembelian ini akan mempengaruhi persediaan yang bersangkutan, yaitu mengurangi kuantitas persediaan dalam kartu gudang dan mengurangi kuantitas dan harga pokok pesediaan.

$>$ Dokumen

Dokumen yang digunakan dalam prosedur pencatatan harga pokok persediaan yang dikembalikan kepada pemasok adalah: laporan pengiriman barang dan memo debit. Laporan pengiriman barang digunakan oleh Bagian Gudang untuk mencatat kuantitas persediaan yang dikirimkan kembali kepada pemasok ke dalam kartu gudang. Memo debit yang diterima dari Bagian Pembelian digunakan oleh Bagian Kartu Persediaan untuk mencatat kuantitas dan harga pokok persediaan yang dikembalikan kepada pemasok ke dalam kartu persediaan.

$>$ Bagan Alir Dokumen Prosedur Pencatatan Harga Pokok Persediaan yang Dikembalikan kepada pemasok. 
Bagian Gudang mencatat berkurangnya persediaan karena transaksi retur pembelian berdasarkan dokumen memo debit yang diterima dari Bagian Pembelian. Memo debit ini dicatat oleh Bagian Gudang di dalam kartu gudang.

g) Prosedur permintaan dan pengeluaran barang gudang

$>$ Deskripsi prosedur

Dalam prosedur ini dicatat harga pokok persediaan bahan baku, bahan penolong, bahan habis pakai pabrik, dan suku cadang yang dipakai dalam kegiatan produksi dan kegiatan non produksi.

$>$ Dokumen

Dokumen sumber yang dipakai dalam prosedur ini adalah bukti permintaan dan pegeluaran barang gudang. Bukti ini dipakai oleh Bagian Gudang untuk mencatat pengurangan persediaan karena pemakaian intern. Bukti ini juga digunakan sebagai dokumen sumber pancatatan pemakaian persediaan ke dalam jurnal pemakaian bahan baku atau jurnal umum.

> Bagan Alir Dokumen Prosedur Permintaan dan Pengeluaran Barang Gudang Karena umumnya perusahaan manufaktur menyelenggarakan persediaan untuk bahan bakunya, maka guna pengambilan bahan baku dari gudang, digunakan permintaan dan pengeluaran barang gudang.prosedur ini digunakan untuk meminta dan mengeluarkan barang-barang yang digudangkan seperti bahan baku, bahan penolong, suku cadang, dan lain sebagainya.

h) Prosedur pencatatan tambahan harga pokok persediaan karena pengembalian barang gudang

$>$ Deskripsi Prosedur

Transaksi pengembalian barang gudang mengurangi biaya dan menambah persediaan barang di gudang.

Dokumen

Dokumen yang digunakan dalam prosedur pengembalian barang gudang adalah bukti pengembalian barang gudang. Dokumen ini digunakan oleh Bagian Gudang untuk mencatat tambahan kuantitas persediaan ke dalam kartu gudang. Dokumen ini juga dipakai oleh Bagian Kartu Persediaan untuk mencatat tambahan kuantitas dan harga pokok persediaan ke dalam kartu persediaan, untuk mencatat berkurangnya biaya ke dalam kartu biaya ke dalam kartu biaya dan untuk mencatat pengembalian barang gudang tersebut ke dalam jurnal umum.

> Bagan Alir Prosedur pencatatan tambahan harga pokok persediaan karena pengembalian barang gudang

Bahan baku yang sudah diminta oleh fungsi produksi adakalanya tidak semuanya habis dikonsumsi untuk memproduksi pesanan tertentu. Jika terjadi kelebihan bahan baku yang diminta oleh fungsi produksi, bahan baku tersebut harus dikembalikan ke fungsi gudang. Pengembalian barang gudang dan pengurangan biaya sebagai akibat pengembalian barang tersebut dilakukan dengan prosedur pengembalian barang gudang.

Dalam hal ini bagian jurnal mencatat pengembalian bahan baku dari bagian produksi ke bagian gudang ke dalam jurnal umum berdasarkan bukti pengembalian barang gudang. Jurnal yang dibuat oleh bagian jurnal untuk mencatat pengembalian bahan baku adalah sebagai berikut: 
Persediaan bahan baku Barang dalam proses
$\mathrm{XX}$

$\mathrm{XX}$

Pendebitan rekening persediaan bahan baku dirinci oleh bagian kartu persediaan ke dalam kartu persediaan berdasarkan bukti pengembalian barang gudang. Pengkreditan rekening barang dalam proses dirinci oleh bagian kartu biaya kedalam kartu harga pokok produk pesanan yang bersangkutan berdasarkan bukti pengembalian barang gudang.

i) Sistem penghitungan fisik persediaan

Bagian Kartu Persediaan menyelenggarakan catatan akuntansi berupa kartu persediaan yang digunakan untuk mencatat mutasi setiap jenis persediaan yang disimpan di Bagian Gudang. Sistem penghitungan fisik persediaan umumnya digunakan oleh perusahaan untuk menghitung secara fisik persediaan yang disimpan di gudang, yang hasilnya digunakan untuk meminta pertanggungjawaban Bagian Gudang mengenai pelaksanaan fungsi penyimpanan, dan pertanggungjawaban Bagian Kartu Persediaan mengenai keandalan catatan persediaan yang diselenggarakannya, serta untuk melakukan penyesuaian terhadap catatan persediaan di Bagian Kartu Persediaan.

Dokumen yang digunakan untuk merekam, meringkas, dan membukukan hasil penghitungan fisik persediaan adalah:

$>\quad$ Kartu penghitungan fisik digunakan untuk merekam hasil penghitungan fisik persediaan.

$>$ Daftar hasil peghitungan fisik. Digunakan untuk meringkas data yang telah direkam.

$>$ Bukti memorial. Digunakan untuk membukukan penyesuaian rekening persediaan sebagai akibat dari hasil penghitungan fisik kedalam jurnal umum.

Menurut Mulyadi (2010:579) fungsi yang terkait dalam melaksanakan perhitungan fisik persediaan adalah:

$>\quad$ Panitia penghitungan fisik persediaan. Panitia ini berfungsi untuk melaksanakan penghitungan fisik persediaan dan menyerahkan hasil penghitungan tersebut kepada Bagian Kartu Persediaan untuk digunakan sebagai dasar penyesuaian terhadap catatan persediaan dalam kartu persediaan.

$>\quad$ Fungsi akuntansi. Fungsi ini bertanggungjawab mencantumkan harga pokok satuan persediaan, mengalihkan kuantitas dan harga pokok per satuan, mencantumkan harga pokok total, melakukan penyesuaian terhadap kartu persediaan berdasarkan data hasil perhitungan fisik persediaan, membuat bukti memorial untuk mencatat penyesuaian data persediaan.

$>\quad$ Fungsi gudang. Dalam sistem ini penghitungan fisik persediaan, fungsi gudang bertanggungjawab untuk melakukan penyesuaian data kuantitas persediaan yang dicatat dalam kartu gudang berdasarkan hasil penghitungan fisik persediaan.

\section{5) Penelitian Terdahulu}

Untuk mendukung penelitian, berikut dikemukakan hasil penelitian terdahulu yang berhubungan dengan penelitian ini :

Tabel Kajian Terdahulu

\begin{tabular}{|l|l|l|l|}
\hline No & \multicolumn{1}{|c|}{ Nama } & \multicolumn{1}{c|}{ Persamaan } & \multicolumn{1}{c|}{ Perbedaan } \\
\hline 1. & $\begin{array}{l}\text { Fitri Yanti }(2011: 1) \\
\text { Sistem Pencatatan }\end{array}$ & $\begin{array}{l}\text { Sumber Data : } \\
\text { Primer dan sekunder }\end{array}$ & $\begin{array}{l}\text { Judul : } \\
\text { Sistem Pencatatan }\end{array}$ \\
\hline
\end{tabular}




\begin{tabular}{|c|c|c|c|}
\hline & $\begin{array}{l}\text { Persediaan pada Mini } \\
\text { Market Jaya Indah }\end{array}$ & $\begin{array}{l}\text { Tekhnik Analisis Data : } \\
\text { Kualitatif } \\
\text { Hasil Penelitian : } \\
\text { hasil penelitian ini membuktikan } \\
\text { bahwa Mini Market Jaya Indah } \\
\text { belum menggunakan system } \\
\text { pencatatan persediaan dengan } \\
\text { baik, maka dari itu karyawati } \\
\text { kesulitan untuk mengetahui } \\
\text { jumlah persediaan barang. }\end{array}$ & $\begin{array}{l}\text { Persediaan pada Mini } \\
\text { Market Jaya Indah } \\
\text { Jenis Penelitian : } \\
\text { Deskriptif } \\
\text { Rumusan Masalah : } \\
\text { Bagaimana sistem } \\
\text { pencatatan yang baik pada } \\
\text { Mini Market Jaya Indah } \\
\text { Operasional Variabel: } \\
\text { Sistem pencatatan } \\
\text { persediaan }\end{array}$ \\
\hline 2. & $\begin{array}{l}\text { Astri Fonda (2011:23) } \\
\text { Analisis Sistem } \\
\text { Penyaluran Kredit } \\
\text { Modal Kerja pada PT } \\
\text { Bank Sumsel Babel A. } \\
\text { Rivai Palembang }\end{array}$ & $\begin{array}{l}\text { Sumber Data : } \\
\text { Data Primer dan Sekunder } \\
\text { Tehnik Analisis Data : } \\
\text { Kualitatif } \\
\text { Hasil Penelitian : } \\
\text { Hasil penelitian ini membuktikan } \\
\text { bahwa pihak Bank tidak cermat } \\
\text { dan teliti dalam } \\
\text { mempertimbangkan kredit yang } \\
\text { akan diberikan sehingga sering } \\
\text { terjadi kredit macet. Sebaiknya } \\
\text { dalam penyaluran kredit lebih } \\
\text { efektif kepada calon debitur } \\
\text { sehingga kemungkinan } \\
\text { terjadinya kredit macet dapat } \\
\text { diantisipasi. }\end{array}$ & $\begin{array}{l}\text { Judul : } \\
\text { Analisis Sistem Penyaluran } \\
\text { Kredit Modal Kerja pada PT } \\
\text { Bank Sumsel Babel A. Rivai } \\
\text { Palembang } \\
\text { Jenis Penelitian : } \\
\text { Deskriptif } \\
\text { Rumusan Masalah : } \\
\text { 1. Faktor-faktor yang } \\
\text { menjadi pertimbangan } \\
\text { dalam menyetujui pinjaman } \\
\text { kredit } \\
\text { 2. Bagaimanasistem } \\
\text { penyaluran kredit pada PT } \\
\text { Bank Sumsel Babel A. Rivai } \\
\text { Palembang. } \\
\text { Operasional Variabel : } \\
\text { Sistem Penyaluran Kredit } \\
\text { Modal Kerja. }\end{array}$ \\
\hline
\end{tabular}

C. METODE PENELITIAN

1) Operasional Variabel

Operasional variabel pada penelitian ini adalah sebagai berikut:

Tabel Operasional Variabel

\begin{tabular}{|l|l|l|}
\hline \multicolumn{1}{|c|}{ Variabel } & \multicolumn{1}{|c|}{ Definisi } & \multicolumn{2}{c|}{ Indikator } \\
\hline Sistem & Mulyadi (2010:553) sistem akuntansi & Prosedur \\
Akuntansi & persediaan bertujuan untuk pencatatan & pengembalian barang \\
Persediaan & mutasi setiap jenis persediaan yang disimpan & atau persediaan \\
& di gudang. Dalam perusahaan manufaktur, & bahan baku ke \\
& persediaan terdiri dari persediaan produk jadi, & gudang. \\
& persediaan produk dalam proses, persediaan & \\
& bahan baku, persediaan bahan penolong, & \\
& persediaan bahan habis pakai pabrik, & \\
& persediaan suku cadang. & \\
\hline
\end{tabular}




\section{2) Objek Penelitian}

Penelitian dilakukan di CV. Ananda Putra Banyuasin yang terletak di Jalan Palembang-Betung Kecamatan Talang Kelapa.

\section{3) Populasi dan Sampel}

Populasi adalah wilayah generalisasi yang terdiri atas objek atau subjek yang mempunyai kualitas dan karakteristik tertentu yang ditetapkan oleh peneliti untuk dipelajari dan kemudian ditarik kesimpulanya (Sugiyono, 2010:80). Populasi penelitian ini adalah seluruh prosedur yang bersangkutan dengan sistem akuntansi persediaan.

Sampel adalah bagian dari jumlah dan karakteristik yang dimiliki oleh populasi tersebut (Sugiyono, 2010:81). Sampel dari penelitian adalah prosedur pencatatan tambahan harga pokok persediaan karena pengembalian barang gudang.

\section{4) Jenis dan Sumber Data}

Jenis data yang digunakan dalam penelitian ini adalah data sekunder. Menurut Indrianto dan Supomo (2002:147) data sekunder yaitu data penelitian yang yang diperoleh secara tidak langsung dan melalui perantara (diperoleh dan dicatat oleh pihak lain). Data sekunder umumnya berupa bukti, catatan atau laporan historis yang telah disusun dalam arsip (data dokumen) yang dipublikasikan dan yang tidak dipublikasikan serta bersumber dari buku-buku pedoman, literatur yang disusun oleh para ahli yang berhubungan dengan masalah yang sedang dianalisis.

\section{5) Teknik Pengumpulan Data}

Dalam pengumpulan data yang diperlukan, penulis menggunakan beberapa cara atau metode yang digunakan dalam pengumpulan data yaitu wawancara, observasi, dan dokumen. Menurut Hasan (2002:17) wawancara yaitu merupakan teknik pengumpulan data untuk mendapatkan informasi yang digali dari sumber data langsung melalui percakapan atau tanya jawab dengan karyawan yang bersangkutan pada CV. Ananda Putra Banyuasin. Observasi yaitu pengamatan terhadap suatu objek uang diteliti baik secara langsung maupun tidak langsung untuk memperoleh data yang harus dikumpulkan dalam penelitian. Dokumen yaitu merupakan rekaman kejadian masa lalu yang ditulis atau dicetak, dapat berupa catatan, surat, buku harian dan dokumen-dokumen.

\section{6) Teknik Analisis Data}

Metode analisis yang akan digunakan dalam penelitian ini adalah metode analisis kuantitatif. Menurut Hasan (2002:32) metode analisis kuantitatif yaitu analisis data dimana datanya tidak dinyatakan dalam bentuk angka-angka yang dapat diukur. Analisis kuantitatif juga dapat menganalisa data yang ada dengan cara mengumpulkan data yang berkaitan dengan sistem akuntansi persediaan yang diperoleh saat penelitian, kemudian membandingkan serta menganalisa data yang diperoleh tersebut untuk disimpulkan dengan teori yang ada.

\section{HASIL PENELITIAN DAN PEMBAHASAN}

\section{1) Prosedur Pengembalian Persediaan ke Gudang}

Prosedur pengembalian dan pencatatan persediaan bahan baku yang tidak habis dalam satu kali produksi menurut Mulyadi (2010:439) adalah sebagai berikut: 
Prosedur pengembalian sisa persediaan yang tidak habis dalam satu kali produksi dapat dijelaskan sebagai berikut:

$>$ Dimulai dari bagian produksi yang membuat dokumen berupa BPBG (Bukti Pengembalian Barang Gudang) dalam tiga rangkap. Dokumen BPBG yang pertama dan yang kedua diserahkan kepada bagian gudang bersama dengan barang atau sisa persediaan bahan baku, sedangkan dokumen BPBG yang ketiga disimpan sebagai arsip untuk bagian produksi.

> Pada bagian gudang, BPBG yang pertama ditandatangani sebagai tanda terima barang atau sisa persediaan yang diberikan oleh bagian gudang. Selanjutnya dokumen BPBG yang pertama digunakan untuk membuat Kartu Gudang keudian BPBG yang pertama diserahkan kepada bagian kartu persediaan. Sedangkan dokumen BPBG yang kedua disimpan sebagai arsip untuk bagian gudang.

> Selanjutnya bagian kartu persediaan mengisi harga pokok pada BPBG pertama yang diserahkan oleh bagian gudang. Selanjutnya BPBG petama tersebut digunakan untuk membuat kartu persediaan, kemudian BPBG tersebut diserahkan kepada bagian kartu biaya.

> Pada bagian kartu biaya BPBG yang diserahkan akan digunakan untuk membuat kartu harga pokok produk. Selanjutnya BPBG tersebut diserahkan kepada bagian jurnal.

$>\quad$ Pada bagian jurnal BPBG tersebut digunakan untuk membuat jurnal umum dan selanjutnya BPBG disimpan sebagai arsip untuk bagian jurnal.

Bahan baku yang sudah diminta oleh fungsi produksi adakalanya tidak semuanya habis dikonsumsi untuk memproduksi pesanan tertentu. Jika terjadi kelebihan bahan baku yang diminta oleh fungsi produksi, bahan baku tersebut harus dikembalikan ke fungsi gudang. Pengembalian barang gudang dan pengurangan biaya sebagai akibat pengembalian barang tersebut dilakukan dengan prosedur pengembalian barang gudang.

Pada gambar tersebut bagian jurnal mencatat pengembalian bahan baku dari bagian produksi ke bagian gudang ke dalam jurnal umum berdasarkan bukti pengembalian barang gudang. Jurnal yang dibuat oleh bagian jurnal untuk mencatat pengembalian bahan baku adalah sebagai berikut :

\section{Persediaan bahan baku} Barang dalam proses
$\mathrm{XX}$

$X X$

Pendebitan rekening persediaan bahan baku dirinci oleh bagian kartu persediaan ke dalam kartu persediaan berdasarkan bukti pengembalian barang gudang. Pengkreditan rekening barang dalam proses dirinci oleh bagian kartu biaya kedalam kartu harga pokok produk pesanan yang bersangkutan berdasarkan bukti pengembalian barang gudang.

\section{2) Prosedur Pencatatan Tambahan Harga Pokok Persediaan karena Pengembalian Barang Gudang}

Transaksi pengembalian barang gudang mengurangi biaya dan menambah persediaan barang di gudang. Jurnal yang dibuat untuk mencatat transaksi tersebut dalam jurnal umum adalah : 


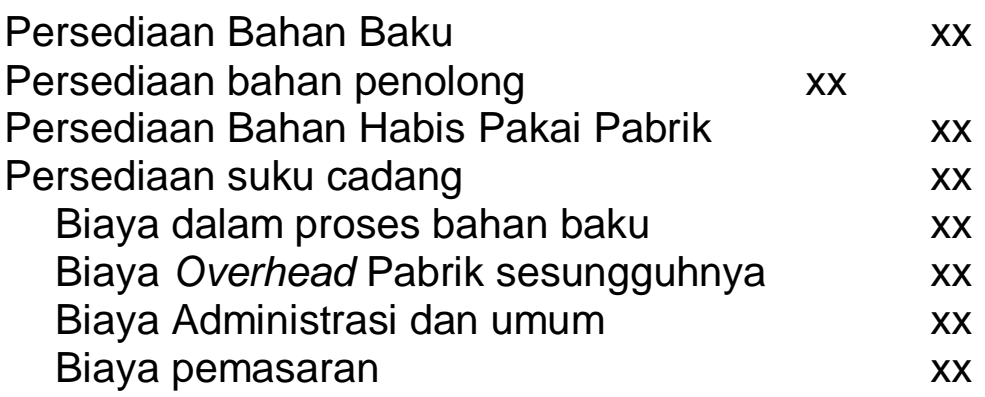

\section{3) Dokumen atau Bukti Pengembalian Persediaan ke Gudang}

Dokumen yang digunakan oleh prosedur pengembalian barang gudang adalah bukti pengembalian barang gudang. Dokumen ini di gunakan oleh bagian gudang untuk mencatat tambahan kuantitas persediaan ke dalam kartu gudang. Dokumen ini juga dipakai oleh bagian kartu persediaan untuk mencatat tambahan kuantitas dan harga pokok persediaan ke dalam kartu persediaan, untuk mencatat berkurangnya biaya ke dalam kartu biaya, dan untuk mencatat pengembalian barang gudang tersebut ke dalam jurnal umum.

Dokumen ini merupakan formulir yang digunakan oleh fungsi produksi untuk mengembalikan bahan baku dan bahan penolong ke fungsi gudang. Pengembalian bahan ini umumnya disebabkan karena adanya sisa bahan baku dan bahan penolong yang tidak habis pakai dalam proses produksi.

\section{4) Hasil Analisis}

Proses produksi vinir menggunakan persediaan bahan baku seperti kayu sengon. Apabila bahan baku berupa sengon tidak habis dalam satu kali produksi, maka persediaan tersebut akan dikembalikan ke gudang. Dalam prosedur pengembalian persediaan ke gudang pada CV. Ananda Putra Banyuasin, tidak ada bukti tertulis berupa dokumen atau surat pengembalian persediaan bahan baku ke gudang, akibatnya petugas Bagian Gudang sering lupa melaporkan ke Bagian Persediaan bahwa terdapat persediaan yang dikembalikan ke gudang. Sehingga sering terjadi selisih antara catatan persediaan bahan baku Bagian Gudang dengan catatan persediaan bahan baku yang dimiliki oleh Bagian Kartu Persediaan (Akuntansi).

Dari data prosedur pengembalian persediaan bahan baku pada perusahaan, terdapat beberapa kelemahan yaitu sebagai berikut:

$\checkmark$ Tidak adanya bukti dan dokumen pengembalian persediaan ke gudang yang akan mengakibatkan petugas gudang sering lupa melaporkan catatan persediaan bahan baku ke bagian kartu persediaan (akuntansi) sehingga akan terjadi selisih catatan persediaan bahan baku bagian gudang dengan bagian kartu persediaan (akuntansi).

$\checkmark$ Dalam prosedur tersebut terlihat jelas bahwa fungsi akuntansi merangkap semua tugas untuk pembuatan kartu persediaan, jurnal umum dan kartu harga pokok produk, dalam hal ini dapat mengakibatkan terjadinya kecurangan.

\section{E. KESIMPULAN DAN SARAN}

1. Kesimpulan

a) Tidak adanya bukti dan dokumen pengembalian persediaan ke gudang yang akan mengakibatkan petugas gudang sering lupa melaporkan catatan persediaan bahan baku ke Bagian Kartu Persediaan (akuntansi) sehingga akan 
terjadi selisih catatan persediaan bahan baku Bagian Gudang dengan Bagian Kartu Persediaan (Akuntansi).

b) Dalam prosedur pengembalian pesediaan ke gudang terlihat bahwa fungsi Akuntansi merangkap semua tugas untuk pembuatan Kartu Persediaan, Jurnal Umum dan Kartu Harga Pokok Produk, dalam hal ini dapat mengakibatkan terjadinya kecurangan yang dilakukan Petugas Bagian Akuntansi terhadap Perusahaan.

2. Saran

a) Hendaknya perusahaan membuat bukti pengembalian persediaan bahan baku ke gudang untuk menghindari terjadi selisih antara catatan persediaan Bagian Gudang dengan catatan persediaan Bagian Kartu Persediaan (Akuntansi).

b) Sebaiknya perusahaan memisahkan tugas Bagian Akuntansi untuk menghindari terjadinya kecurangan. Kartu persediaan sebaiknya dibuat oleh Bagian Kartu Persediaan, Kartu Harga Pokok Produk sebaiknya dikelola oleh Bagian Kartu Biaya, dan Jurnal Umum sebaiknya dicatat oleh Bagian Jurnal.

\section{DAFTAR PUSTAKA}

Hasan M. Iqbal.2002.Materi Statistik I. Edisi Kedua.PT.Bumi Aksara : Jakarta

Indrianto, Nur.2002.Metodologi Penelitian Bisnis Untuk Akuntansi dan Manajemen. Edisi Pertama. BPFE. Yogyakarta

Krismiaji. 2010. Sistem Informasi Akuntansi. Edisi 2. Penerbit Akademi ManajemenPerusahaan YKPN : Yogyakarta

Mulyadi. 2010. Sistem Akuntansi. Penerbit Erlangga : Jakarta

Oktariansyah. 2018. Perencanaan dan Pengendalian Persediaan Barang Dagang Pada CV. Biji Kopi Makmur Indralaya. Jurnal Media Wahana Ekonomika, Vol 16 No. 1 April 2019, Hal: 65-80.

Rudianto. 2009. Pengantar Akuntansi. Penerbit Erlangga : Jakarta

Soemarso S.R. 2004. Akuntansi Suatu Pengantar. Penerbit Salemba Empat : Jakarta

Sugiyono. 2010. Metode Penelitian Kuantitatif Kualitatif dan R\&D. Penerbit Alfabeta : Bandung.

Widjajanto, Nugroho. 2001. Sistem Informasi Akuntansi. Penerbit Erlangga : Jakarta

Winarno, Wahyu Wing. 2006. Sistem Informasi Akuntansi. Penerbit STIM YKPN : Yogyakarta

Yanti, Fitri. 2011. Sistem Pencatatan Persediaan pada Mini Market Jaya Indah. Universitas PGRI Palembang. Skripsi 